\title{
Some Useful Lessons from Richard Rorty's Political Philosophy for Philippine Postcolonialism
}

\section{F. P. A. Demeterio}

\begin{abstract}
National pride is to countries what self-respect is to individuals: a necessary condition for self-improvement. Too much national pride can produce bellicosity and imperialism, just as excessive self-respect can produce arrogance. But just as too little self-respect makes it difficult for a person to display moral courage, so insufficient national pride makes energetic and effective debate about national policy unlikely. - Richard Rorty ${ }^{1}$
\end{abstract}

\section{General Introduction}

$\mathrm{R}$ ichard McKay Rorty (1931-2007), undoubtedly one of the greatest American philosophers of the late twentieth- and early twenty-firstcenturies, was a professor of philosophy, humanities, and comparative literature at the universities of Princeton, Virginia, and Stanford. He started his philosophical journey by immersing himself in the idealism of Plato (428-347 B.C.), and in the dialectics of G.W.F. Hegel (1770-1831), but unable to find intellectual satisfaction from them, he returned to the pragmatism of his parents' friend John Dewey (1859-1952).

But Rorty's journey back to the familial pragmatic philosophy had been tempered with his exposure to Jacques Derrida (1930-2004), Martin Heidegger (1889-1976) and Ludwig Wittgenstein (1889-1951), making his neopragmatic musings a blend of the state of the art of theorizing from both the twentieth-century Anglo-American and the post-Nietzschean continental traditions. As to his distinctive leftist political leaning, he traces them back to a boyhood that was nurtured by steadfast Trotskyist, socialist, and labor activist parents. ${ }^{2}$

He served as president of the American Philosophical Association and ironically developed an anti-philosophical view, that philosophy is not a privileged discourse, which he lived out by taking teaching jobs in humanities and comparative literature. When he died of pancreatic cancer, he left behind a

\footnotetext{
1 Achieving Our Country: Leftist Thought in Twentieth-Century America (Cambridge, Massachusetts: Harvard University Press, 1998).

${ }^{2}$ Richard Rorty, Philosophy and Social Hope (London: Penguin Books, 1999), 5-8.
} 


\section{RICHARD RORTY'S POLITICAL PHILOSOPHY}

body of works that possesses astounding implications not only on contemporary metaphysics, epistemology, ethics, and political philosophy, but also on social and cultural theories.

Philippine postcolonialism has its early origins in the late nineteenthcentury nationalistic writings from the propaganda movement, the anti-Spanish revolution and the early American period. Its growth, however, was stunted by the systematic reformation of the Filipino mind with Anglo-American literature, values and culture. It began to redevelop only in the 1950s, in the colonial set-up of the University of the Philippines. By the 1970s and 1980s, our local postcolonialism had already fostered three robust schools of thought, the Sikolobiyang Pilipino, Pilipinolobiya, and Pantayong Pananaw. However, after more than half a century from its full emergence in 1950s, our local postcolonialism seems to have remained confined within our progressive academic centers, unable to fully alter the tone of our collective academic discourses, and unable to unshackle the colonial bondage of the Filipino mind.

In this this paper, I will attempt to extract some insights from Rorty's neo-pragmatic political philosophy with the aim of enriching and fortifying our local postcolonial projects by giving justice to their agenda and methods, critiquing their current status, and providing them a clearer sense of direction and vision. As a preliminary step in order to accomplish this core task this paper would take a look at three things: 1) the main tenets of Rorty's political philosophy; 2) the highlights of Philippine post-colonial researches and theorizations; and 3) the epistemological, political, directional and modal difficulties encountered by these local post-colonial projects.

\section{Rorty's Neopragmatic Political Philosophy}

Rorty self-consciously places himself within the pragmatic tradition, a school of thought founded by Charles Sanders Peirce (1839-1914), popularized by William James (1842-1910), and philosophically expounded by F.C.S. Schiller (1864-1937) and John Dewey. Pragmatism, the most dominant American philosophy during the early part of the twentieth century, hinges on the ideas that theories are conceptual tools that man uses in grappling with whatever project or concern he has at hand, and therefore the 'truthfulness' of such ideas and theories is measured by their success in accomplishing their specific tasks. Pragmatists do not actually ask whether a particular theory is true or false, rather they ask whether a particular theory has proven itself effective or not. Their core interest in epistemology spreads through the studies of law, education, politics, social theory, and culture (Thayer, 1992, p. 636).

If Peirce, James, Schiller and Dewey were the classic American pragmatists, Rorty identifies W.V.O. Quine (1908-2000), Nelson Goodman (1906-1998), Hilary Putnam (born: 1926) and Donald Davidson (1917-2003) as the leading neo-pragmatists. ${ }^{3}$ He points out that what differentiates the neo-

${ }^{3}$ Ibid., 25. 


\section{F. DEMETERIO}

pragmatists from the classical pragmatists is the so-called 'linguistic turn' that happened during the 1940s and 1950s when these younger philosophers, taking their cue from Gottlob Frege (1848-1925), abandoned the classic analysis of experience in favor of the analysis of language.

Although Rorty took this same linguistic turn, he insists that he aligns himself more with Dewey's philosophy. "The philosopher whom I most admire, and of whom I should most like to think of myself as a disciple," he writes, "is John Dewey." 4 His reason for doing so is that Dewey was the one who convinced him to abandon the Platonic and Kantian search for the timeless and normative foundations of human knowledge and actions, and inspired him instead to focus on the sustained and systematic hoping for the betterment of humanity.

As a neo-pragmatist, Rorty distinguishes himself from the group of Quine, Goodman, Putnam and Davidson, by highlighting his concern for ethics, politics, and the American culture, which this group had thematically neglected. He explains that the other neo-pragmatists had been bound by the spell of Rudolf Carnap (1891-1970) who insisted that philosophy should focus on logic and should steer away from politics and culture. ${ }^{5}$ Quine happened to be a student of Carnap, while Goodman and Davidson happened to be students of Quine. Although Putnam was able to wiggle out of this Carnapian boundary, he did so only in the later part of his philosophical career. Another crucial difference between Rorty and the other neo-pragmatists is that they are steeped in the Anglo-American analytic tradition, while he is constructively exposed to the post-Nietzschean continental tradition.

Rorty's political philosophy, although more engaging and earthly than his rather abstruse epistemology and ethics, is intimately connected with them. Hence, before tackling the political aspects of his thought, it is necessary to have a cursory look on his theories of truth, mind, and ethics, as well as on his idea of what philosophy ought to be.

\section{Theory of Truth}

Rorty's theory of truth can be more easily grasped when seen as a reaction against the two dominant and older theories of truth. The first of these is the correspondence theory, which claims that a statement is true if such statement agrees with the reality it describes. The second of these is the coherence theory, which claims that a statement is true if such statement agrees with its kindred statements within a given system of knowledge. After the socalled 'linguistic turn' both theories of truth encountered some radical crises.

In an epoch when reality is considered as basically chaotic and unknowable and as intelligible only through language, the theory of correspondence lost its guarantor of truth. Beyond the statement is now an incomprehensible and unintelligible terrain. There is no more point in looking

\footnotetext{
${ }^{4}$ Ibid., xvi.

${ }^{5}$ Ibid., 25.
} 


\section{RICHARD RORTY'S POLITICAL PHILOSOPHY}

for any possible agreement between such statement and the flux of reality that it describes. After the linguistic turn what remains is the statement, and without the possibility of its empirical verification, the correspondence theory of truth ceases to make sense.

In this same epoch, even the coherence theory of truth, which was supposed to be autonomous from reality, is shaken to its very foundation. At a closer look, the coherence theory would turn out to be not absolutely autonomous from reality, for it requires that in a given system of knowledge at least some of its statements are empirically verifiable. For the coherence theory, it is these empirically verifiable statements that serve as anchors to prevent a given system of knowledge from soaring freely towards the heavens. Without aspects of the real world to latch on to, a system of knowledge could still be perfectly coherent, but it is exposed to the danger of being totally nonsensical and irrelevant. Hence, after the linguistic turn, the coherence theory is seriously disabled.

To prevent intellectual nihilism and anarchy, Rorty replaces the correspondence theory with the pragmatist theory of truth, where a statement is no longer seen as a report of some aspects of reality, but a conceptual tool that man utilizes in accomplishing a given task. Pragmatists, as already mentioned, measure the 'truthfulness' of a statement no longer by its agreement with the reality it describes, but by its effectiveness in accomplishing its intended task.

On the other hand, Rorty's adaptation of the pragmatic theory of truth remedied the crisis encountered by the coherence theory of truth by giving it an additional criterion: a statement is true, not only when it agrees with its kindred statements within a given system of knowledge, but also when it is effective in accomplishing its intended task. Hence, even if the linguistic turn had dissolved the aspects of reality that a system of knowledge could have latched on to, this system of knowledge need not soar towards the nonsensical and irrelevant heavens because it is accountable to the question "are its statements effective in accomplishing their intended tasks?"

Rorty initially emphasizes that ideas and theories that are effective in creating a better future for humanity are true, while those that are ineffective are not true. But sooner he radicalizes the pragmatic theory of truth by arguing that philosophy should stop asking about the nature of truth, for truth may not have a nature in the first place; and man should stop thinking that goal of his inquiries is truth, for to say truth is his goal would mean that he is capable of grasping truth once he attains it. Instead of being obsessed with truth, philosophers should focus on hoping for a better future. Rorty states: "One should stop worrying about whether what one believes is well grounded and start worrying about whether one has been imaginative enough to think up interesting alternatives to one's present beliefs." ${ }^{\prime}$ In the end, he transforms the theory of truth into a theory of hope.

${ }^{6}$ Ibid., 34. 


\section{F. DEMETERIO}

\section{Theory of Mind}

Rorty's theory of truth, or of hope, would become clearer once contextualized in his theory of the mind. In the western world, the idea of the human mind had been predominantly shaped by Rene Descartes (1596-1650), with his image of the mind as something that is prone to error but is nevertheless capable of representing reality through systematic doubting and some stringent methods; as well as by John Locke (1632-1704), with his image of the mind as initially an empty slate that would be gradually filled up with representations of reality through the processes of sensation and reflection. The dominant western idea of the mind is therefore representational, where it is conceptualized as a space, or a stage, in which and upon which reproductions from the real world are created, stored, and recreated.

Rorty argues that with this representational theory of the mind, it is but expected that philosophy sooner or later would be led to the thorny question of how can it be assured that such mental reproductions are faithful to their references in the real world. For him, the only way to avoid this unpleasant problem is to scrap the Cartesian-Lockean representational model, and instead follow the other pragmatists in adopting the causal model proposed by Charles Darwin (1809-1882). He states: "So they start with Darwinian account of human beings as animals doing their best to cope with the environment - doing their best to develop tools which will enable them to enjoy more pleasure and less pain." 7 Concepts, ideas and theories happened to be some of man's most powerful tools.

In the Darwinian causal model, the mind is construed as a tool-making capacity that enables man to deal with the often harsh outside world, and ceases to be a space or stage where thinking is supposed to hapen. In this causal model, the concepts, ideas, and theories that were previously thought to populate the mind are recast by Rorty into linguistic entities. After the linguistic turn, there are no longer such things as pre-linguistic concepts, ideas, and theories. In this epoch, thinking is nothing but a silent monologue where the self articulates ideas, experiences, feelings, intentions and theories through language.

With the Darwinian causal model, the old question on how philosophy can be assured that the concepts, ideas and theories inside the mind are faithful to reality is replaced with the more pressing question on how philosophy can be assured that the concepts, ideas and theories produced by the mind are effective tools in dealing with the contingencies of the outside world.

\section{Ethical Theory}

Rorty's ethical theory could be seen as an elaboration and application of his more central epistemological theory. This theory may be summed up in the statement: actions that are effective in creating a better future for humanity

${ }^{7}$ Ibid., xxii-xxiii. 


\section{RICHARD RORTY'S POLITICAL PHILOSOPHY}

are morally superior than actions that are ineffective. In justifying this pragmatic moral principle, he makes use of Dewey's Darwinian thinking

Dewey explained the emergence of ethics by blurring the difference between 'prudence' and 'morality'. For him, 'prudence,' or 'habit,' or 'custom,' is a routine, semi-conscious and unproblematic response of man to his day to day circumstances. But once man is plunged into a situation which is no longer routine, he realizes that he could not anymore rely on prudence, or habit, or custom. Some examples of this non-routine situation is when this person's needs clashes with those of his family, or when his family's interests collide with those of his neighbors,' or when a once peaceful community is fractured by war due to an economic trigger, or when one society has to deal with another alien society. ${ }^{8}$ In situations like these, man would suddenly find himself in need of some guidelines other than those provided by prudence, habit, or custom. For Dewey and for Rorty, this situation is the beginning of morality. Rorty states: "We invent both (morality and law) when we can no longer just do what comes naturally, when routine is no longer good enough, or when habit and custom no longer suffice." 9 Thus, prudence, habit, custom are merely different from morality and law in terms of degree of articulation and explicitness. In terms of kind and quality, they are all the same in being man's responses to his day to day circumstances.

Just as prudence, habit and custom are there to make man more effective in dealing with his social world, so are morality and law. Instead of grounding morality and law on the inscrutable will of God, Rorty suggests to ask the more earthy question of whether such things are indeed making man more effective in dealing with his social world. In Rorty's DeweyanDarwinian ethical theory, moral progress is seen as man's capacity to factor in more and more people, and more and more aspects of his world, in figuring out which actions could contribute to the creation of a better future for humanity and which actions could only hinder.

\section{The Idea of Philosophy}

In a world that is devoid of substances, essences, objective moral principles, and a world that is practically an unintelligible terrain, we could only wonder what remains to be done for philosophy. As already mentioned, Rorty had adopted an anti-philosophical view that dethroned philosophy as a privileged discourse, and he lived out this belief by taking teaching jobs in humanities and comparative literature. But what is precisely his idea of philosophy? Is it really something antagonistic to the very same discipline from which he is, and unto which, he is theorizing? Is there still something significant left for philosophy to accomplish after the linguistic turn?

Rorty's anti-philosophical view, however, does not really intend to kill philosophy. On the contrary he aims to transform and rehabilitate it to make it

\footnotetext{
8 Ibid., 73

${ }^{9}$ Ibid.
} 
more adaptable to the new epoch where reality is replaced by language. His anti-philosophical view was in fact a preventive theorizing to keep philosophy from dying a natural death.

One of the most conspicuous items in Rorty's idea of philosophy is its lack of substantive difference with the other discourses. He asserts: "For pragmatists there is no sharp break between natural science and social science, nor between social science and politics, nor between politics, philosophy and literature. All areas of culture are parts of the same endeavor to make life better."10

After the linguistic turn, philosophy is no longer expected to search for ultimate truths, or to act as the tribunal of reason that could critique and evaluate institutions and discourses. Instead, it is expected to work hand in hand with the other disciplines in re-describing the world and in expressing hope to make a better place for humanity. Rorty would even think that literature could do this job better than philosophy, for it can more powerfully reinterpret the world and emotively slither into the convictions of its readers.

If there is one special task left for philosophy, it is to lead and join the other discourses in generating new vocabularies, descriptions and interpretations of the world. Michael Lynch, in his essay Richard Rorty, comments: "The goal of the philosopher is not to map the landscape as it is, but change how we see the world; to paint new landscapes, new pictures." 11

But by giving up the function of being the tribunal of reason that could critique and evaluate institutions and discourses, this transformed philosophy would have difficulties in replacing older vocabularies, descriptions, and interpretations. The pragmatic technique of declaring these older items as less effective would hardly suffice for the reason that in this consequentialist counter-argument one would need a longer time frame before a reliable verdict can be delivered. The new items could only be proven to be better than the older items after the new items would have proven themselves effective in time.

Rorty believes that a shift from the old to the new could be attained by emotively convincing the people of the superiority of the new vocabularies, descriptions and interpretations. He explains: "The method is to redescribe lots and lots of things in new ways, until you have created a pattern of linguistic behavior which will tempt the rising generation to adopt it . . .. This sort of philosophy does not work piece by piece, analyzing concept after concept, or testing thesis after thesis. Rather it works holistically and pragmatically."12

With a clearer picture of Rorty's theories of truth, mind, and morality, as well as of his idea of philosophy, it would now be easier to tackle his political philosophy. The following sub-sections, then, would explore his

\footnotetext{
${ }^{10}$ Ibid., xxv.

11 Michael Lynch, "Richard Rorty," in Encyclopedia of Philosophy (Detroit: Thomson Gale, 2006), 495.

12 Richard Rorty, Contingency, Irony and Solidarity (Cambridge: Cambridge University Press, 1989), 9.
} 


\section{RICHARD RORTY'S POLITICAL PHILOSOPHY}

general political theory, his critique of the American Left, and his critique of globalization.

\section{General Political Theory}

With very broad and sweeping strokes, we may think of Rorty's political philosophy as a further elaboration and application of his theories of truth and morality. In this manner, political actions that are effective in creating and building a better future for humanity are considered superior than actions that are less effective. When asked what does 'better' mean for him, Rorty would reply better in the sense of having more freedom, more growth, more empathy, and more solidarity. But when asked further why would more freedom, more growth, more empathy, and more solidarity make the situation better, his otherwise cohesive pragmatic reasoning would break down to give way to his so-called 'liberal ironism'.

Rorty believes that a democratic and liberal government is a better form of political organization. But the irony behind this belief is that it is not something that can be given a philosophical explanation. His liberal ironism is all about refraining from laying down a solid philosophical justification for a particular form of government or ideology which proves itself to be superior to others, because there would never be such justification. Inversely, liberal ironism is all about infusing philosophy with the liberal and democratic ideals of freedom, growth, empathy and solidarity. It is this Rortian political ideology that made him transform philosophy into something that should work hand in hand with other disciplines in re-describing the world and in expressing hope to make it a better place for humanity.

Hence, with finer and more meticulous strokes, we should think of Rorty's theories of truth and morality as further elaboration and application of his political philosophy, and not the other way around.

\section{Critique of the American Left}

As already mentioned, Rorty acknowledges his political leaning as leftist, a kind of leftism that can be traced back to a boyhood nurtured by steadfast Trotskyist, socialist, and labor activist parents. He proudly recounts: "I grew up knowing that all decent people were, if not Trotskyites, at least socialists . . . at 12, I knew that the point of being human was to spend one's life fighting social justice."13 His mature political ideology is expounded more clearly in his critique of the American leftist movement.

He begins his analysis with an emphasis on the significance of the left to a democratic society. He calls it the 'party of hope,' in contrast to the often calcified right that is convinced there is nothing much to be changed from the status quo. ${ }^{14}$ The right believes that the country is basically sound and in good

\footnotetext{
13 Rorty, Philosophy and Social Hope, 6.

${ }^{14}$ Rorty, Achieving Our Country, 14.
} 
shape, and looks at the left as a bunch of trouble-makers and utopian dreamers. But it is actually the left that challenges the society to become better and better. In America, one of the crucial issues that divide the right and the left is whether or not the government should take it as its responsibility to work for a more equitable redistribution of wealth. ${ }^{15}$

Rorty claims that the story of the $20^{\text {th }}$ century American leftist movement is characterized by the succession of three groups: the old left, the new left and the cultural left. For him, this succession is more like a descent into pessimism and political irrelevance instead of an evolution towards a left that is more and more capable of goading the democratic society towards a more egalitarian and prosperous future.

The old left pertains to "those Americans who, between 1900 and 1964, struggled within the framework of constitutional democracy to protect the weak from the strong." 16 For him, this left included liberals and radicals, communists, and socialists, intellectuals, and unionized workers, and many other good-intentioned individuals who manifested their political beliefs in praxis. This is the left to which his parents belonged and to which he identifies himself with. ${ }^{17}$

The old left was consumed with the ideals of Dewey and Walt Whitman (1819-1892) concerning becoming a decent and civilized society, love for country, and pride in being Americans. Despite seeing and being vocal about the shortcomings of their country, the old left was intensely proud of the present and hopeful for the future of America.

This left accomplished so much, not only in improving the plight of the 'people who were humiliated by poverty and unemployment,' but more so in articulating the American spirit. ${ }^{18}$ Rorty explains: "Without the American Left, we might still have been strong and brave, but nobody would have suggested that we were good. As long as we have a functioning political Left, we still have a chance to achieve our country, to make it a country of Whitman's and Dewey's dreams." 19

As America entered into the 1960s, the strain of the Vietnam War, and the sufferings of the African-Americans became a wedge that divided the old left from what would later become the new left, that consisted of "peoplemostly students - who decided, around 1964, that it was no longer possible to work for social justice within the system."20 Rorty notes that with the emergence of the new left, the alliance between the intellectuals and the unionized workers started to drift apart.

\footnotetext{
${ }^{15}$ Ibid., 48.

${ }^{16}$ Ibid., 43.

17 Derek Nystrom and Kent Puckett, "Against Oligarchies: A Conversation with Richard Rorty," in Prickly Paradigm Press, Chicago < $\underline{\text { http://www.prickly- }}$ paradigm.com/paradigm3.pdf>, 14 September 2007.

18 Rorty, Achieving Our Country, 80.

${ }^{19}$ Ibid., 107.

${ }^{20}$ Ibid., 43.
} 


\section{RICHARD RORTY'S POLITICAL PHILOSOPHY}

The new left was a movement that was overcast with hopelessness and pessimism. From its perspective there was something fundamentally wrong with America, sheer reforms cannot rectify this, and, hence, Americans should be ashamed of their country.

Despite its somber outlook, this new left accomplished some important things, such as putting and end to the Vietnam War, diminishing the rather loose powers of the CIA, and imposing a more stringent norm of truthfulness on the Defense Department. ${ }^{21}$ This new left, however, was short lived. During the 1970s, it started to retreat into the sanctuaries of the American colleges and universities to become the academic left.

From the economic and political engagements of the old and the new left, the academe-based intellectuals started to dig deeper into the unconscious motives of oppression using Sigmund Freud's (1856-1939) psychoanalytic lens and focused on sadism. Rorty narrates: "With this partial substitution of Freud for Marx as a source of social theory, sadism rather than selfishness has become the principle target of the Left . . . Many members of this Left specialize in what they call the 'politics of difference' or 'of identity' or 'of recognition'." 22 Thus, instead of studying economic and political oppressions, the cultural left studied the concept of stigmata, such as femininity, homosexuality, and ethnicity; and instead of tracing oppression to human greed, this left delved into the sub-conscious psychosexual dynamics of culture.

The cultural left was not only overcast with hopelessness and pessimism, but with principled, theorized, and philosophical hopelessness and pessimism. It carried no trace of the Deweyan and Whitmanesque ideals that buoyed the American spirit prior to the 1960s.

If the old and the new left accomplished great economic and political changes, the cultural left, similarly has accomplished some remarkable things: the propagation of impressive and scholarly discourses in cultural studies and the reduction of sadism in society, specifically by making male chauvinism, gaybashing, racism, and other forms of intolerance less and less acceptable.

Although the academic left is not the only leftist group in America, it happened to be the most significant left in the country at the moment. Rorty, therefore, airs the necessity that this left should rethink its roles and obligations to American democracy. He points out at least three fundamental problems hounding this left. The first of these pertains to the academic left's overall timbre of hopelessness and pessimism. The right can only give the society its conservative ideology, and it is the left that should goad this same society to grow better and better. But without hope and optimism, the left will never be able to accomplish its fundamental task. Strong Deweyan and Whitmanesque hope and optimism are necessary if the academic left has to push the American society towards higher levels of cultural evolution.

The second of these problems pertains to the academic left's lack of attention to the economic and political components of oppression. Rorty

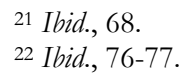


warns that the gains made by the old and the new left are now being eroded by some powerful social changes. Rorty emphasizes: "While the Left's back was turned, the bourgeoisification of the white proletariat which began in the World War II and continued up through the Vietnam War has been halted, and the process has gone into reverse. America is now proletarianizing its bourgeoisie, and this process is likely to culminate in a bottom-up populist revolt . . .."23 While the critique of cultural sadism is good, it should not be done at the expense of studying economic and political sadism. The cultural left must engage again in economic and political criticism to continue the struggles of the old and the new left.

The third of these problems pertains to the academic left's loss of pride for America. Rorty likens national pride to self-respect, which for an individual is a requirement for self-improvement. What a country needs is sufficient pride: too much of it produces arrogance and belligerence, while too little of it produces timidity and lack of interest in political and economic affairs. There is nothing wrong with the cultural left's condemnation of America's wrongdoings, but it should not also remain blind to the great things that America did. Rorty explains: "Those who hope to persuade a nation to exert itself need to remind their country of what it can take pride in as well as what it should be ashamed of. They must tell inspiring stories about episodes and figures in the nation's past-episodes and figures to which the country should remain true." 24

\section{Critique of Globalization}

When Rorty mentioned the idea that the cultural left, by ignoring the economic and political aspects of oppression, had practically allowed the gains made by the old and the new left to be eroded by some powerful social changes, he had at the back of his mind the gargantuan image of globalization. His critique of the American left can even be construed as his way of bracing American democracy, and all the other democracies in the world, against the full impact of globalization.

We usually think that America is one of the few countries that is benefiting from the new global order, but Rorty deems otherwise. He is very clear that the advantages reaped by some few American transnational corporations would not translate into advantages for the whole country. On the contrary, he foresees that America would suffer as much as the other countries if the frenzied globalizing moves would finally spin out of control.

For Rorty, the present trend of American and European companies of putting up offshore operations on the low-wage areas of Asia and Africa, instead of on their respective base-countries, is already bad enough, as this diminishes the additional jobs for their workforce. But the central problem with globalization is the fact that economic activities are going more and more

\footnotetext{
${ }^{23}$ Ibid., 83.

${ }^{24}$ Ibid., 9-4.
} 


\section{RICHARD RORTY'S POLITICAL PHILOSOPHY}

beyond the moderation and control of any one nation. The few transnational corporations are fast gaining their autonomy and freedom to move their capitals and products through national boundaries. By becoming citizens of many countries, these transnational corporations would actually become citizens to none. Without emotional ties and commitment to a motherland, and without solidarity with their fellow citizens, they will just be motivated by profiteering even to the extent of impoverishing their base-country and oppressing their workers.

It would not take very long before a new domineering elite would emerge, an elite that is fewer but immensely more powerful and menacing than the nineteenth-century bourgeois. This global 'overclass' would be the ones to make the major economic decisions for the world, completely unhampered by the legislatures of any one country. In this scenario, citizens of any one country could no longer pressure their political leaders to moderate and control the rampaging moves of this global 'overclass'. Rorty expresses a stern warning: "The money accumulated by this overclass is as easily used for illegal purposes, such as supplying land mines to the latest entrepreneurial warlord or financing gangster takeovers of trade unions, as it is for legal ones." 25

When Rorty suggests to the cultural left that it re-engage with economic and political advocacies like what the old and new left did, he does not mean that the praxiological tasks waiting for the cultural left would be more or less similar to those of the pre-1960s or the pre-1970s. Aside from the local economic and political matters, there are these totally new global economic and political matters that are shouting for the cultural left's immediate attention.

Rorty could only give a general advice on the need for leftist intellectuals, from America and all the other countries, to band together and raise their fellow citizens' consciousness about the dangers and threats spawned by globalization. Both intellectuals and lay people should then convince their respective governments to lobby for a more powerful global polity that would be capable of moderating and controlling the otherwise immoderate and uncontrollable transnational corporations. Rorty states: "Only global political institutions can offset the power of all that marvelously liquid and mobile capital." 26

\section{Postcolonial Discourses in the Philippines}

'Postcolonialism,' as it is known in the West, may be understood as a philosophical, literary, and social scientific critique of the conditions left behind by the European and American colonial dominations. Its emergence may be traced back to the 1950 pamphlet, Discourse on Colonialism, of the Martinican poet, novelist, politician and philosopher Aimé Césaire (1913-2008), and to the 1952 book, Black Skin, White Mask, of another Martinican psychiatrist and

\footnotetext{
25 Rorty, Philosophy and Social Hope, 233.

${ }^{26}$ Ibid., 233-234.
} 
revolutionary Frantz Fanon (1925-1961). Césaire's work examines the brutal impact of capitalism and colonialism on both the colonizer and colonized, and exposes the contradictions and hypocrisy implicit in the western notions of 'progress' and 'civilization,' specially when contrasted with the notions of 'savage,' 'uncultured,' or 'primitive'. Side by side with the decolonization of his Caribbean society, he calls for a decolonization of the Caribbean mind and inner life. Meanwhile, Fanon's work looks beyond the systems of political and economic dominations and focuses on the psychoanalysis and phenomenology of colonialism. He explores the 'inferiorization' and delusions of the colonized psyche, as well as the phobias and anxieties on the part of the colonizer.

Postcolonialism started with the theoretical and analytic tools of the hermeneutes of suspicion, Karl Marx (1818-1883), Freud, and Friedrich Nietzsche (1844-1900), as well as of the existential phenomenologist Jean-Paul Sartre (1905-1980). Later on it appropriated the structuralist and poststructuralist frameworks of Louis Althusser (1918-1990), Michel Foucault (1926-1984), Jacques Lacan (1915-1980) and Derrida.

The postcolonial discourses in the Philippines, however, sprouted independently from the two French-Caribbean theorists. A careful reading of the nationalistic writings from the propaganda movement, the anti-Spanish revolution, and the early American period would easily reveal a number of postcolonial themes, such as the 'inferiorization' of the Indio, the manipulation of knowledge and language, the exploitation of colony, and the yearnings for freedom and independence.

But as the American occupation inundated the Filipino culture with 'civilizing' and 'humanizing' American and English readings, and as a new breed of Filipino writers tried to imitate the form and content of this literature, our nationalistic discourses were marginalized and suppressed, reducing the once fiery Filipino nationalism into a hallow cliché of party politics. Moreover, since these nationalistic discourses were generated during the colonial times, these would not technically qualify as postcolonial writings. Our anti-Hispanic and anti-American musings, then, had to wait for almost half a century before they could be articulated and developed again into full-blown postcolonialism.

After we gained independence from American rule, two streams of thought emerged and later on combined to generate a full-blown tradition of Philippine postcolonial discourses. The first of these streams was the revitalized nationalism emanating from Claro M. Recto's (1890-1960) politicaleconomic critique of our country's foreign policy that inspired a number of politicians and intellectuals to unmask our bondage to American neocolonialism. ${ }^{27}$ The most notable among Recto's followers were Leon Maria Guerrero, Lorenzo Tanada, Jose W. Diokno, and Renato Constantino.

The second of these streams pertained to the acute crisis experienced by some social scientists at the University of the Philippines upon realizing the

27 Cf. Erwin Soriano Fernadez, "Decolonizing the Filipino: Cultural Intellectual Revolution in Contemporary Philippines," in Asia Culture Forum $2006<\mathrm{At}$ http://www.cct.go.kr/data/acf2006/aycc/aycc1402Erwin $\% 20$ Soriano $\% 20$ Fernandez.pdf> , 03 October 2007. 


\section{RICHARD RORTY'S POLITICAL PHILOSOPHY}

fundamental incongruity between the Western social theories that they learned abroad and the Philippine realities that they were investigating. ${ }^{28}$ The story behind this academic crisis is intimately bound to the history of our country's prime university. In 1908, the University of the Philippines started out with its all-American faculty and administrators, but sooner it realized that it would be much cheaper for the American government to train Filipino academicians in the United States and bring them back to staff the same university. The Filipino recipients of this scheme came to be known as the pensionados, and the earliest of them naively struggled to uncritically transplant on our native soil the theories they learned in America. But as their research requirements dictated that they do more and more field work, it dawned on them that their imported framework simply would not fit squarely on the Philippine realities. ${ }^{29}$

Sooner, Rectos' revitalized nationalism and the pensionados' search for local alternative frameworks coalesced into a social theory that is both nationalist and anti-colonial. In the 1950s and 1960s, our local postcolonialism retained its independence from Césaire and Fanon's foundational works.

Lily Mendoza, in her work Between the Homeland and the Diaspora, recounts the names of some other pioneering Filipino postcolonialists: Leonardo Mercado in philosophy; F. Landa Jocano, Ponciano Bennagen, and Prospero Covar in anthropology; Felipe De Leon in humanities; Virgilio Enriquez in psychology; and Zeus Salazar in history. ${ }^{30}$ To her rather limited list we may add Teodoro Agoncillo in history; F. Sionil Jose, Beinvenido Lumbera and Isagani Cruz in literature; Alice Guillermo and Nicanor Tiongson in humanities; and Walden Bello in social economics.

Among these innovative Filipino critics and scholars, Enriquez, Covar and Salazar stand out for having generated the enduring schools of thought, Sikolobiyang Pilipino, Pilipinolohiya and Pantayong Pananaw. Mendoza states: "These three. . . would constitute the triumvirate in the indigenization movement, each making strategic contributions to the common endeavor of constructing a national discourse on civilization." 31 Our discussion on Philippine postcolonial discourses, therefore, would focus on the theories and legacies of these three thinkers.

\section{Enriquez and Sikolohiyang Pilipino}

Virgilio G. Enriquez (1939-1994) 32 started his career as a psychology professor at the University of the Philippines. As early as 1965, he was already using Filipino as his medium of instruction. He earned his doctor's degree in social psychology from Northwestern University, in Illinois, in 1970. Back in

\footnotetext{
28 Cf. Lily Mendoza, Between the Homeland and the Diaspora: the Politics of Theorizing

Filipino and Filipino American Identities (Manila: UST Publishing House, 2006), 52.

${ }^{29}$ Ibid., 53.

${ }^{30}$ Ibid., 54-63.

${ }^{31}$ Ibid., 63.

32 This year of birth, 1939, is extrapolated from the fact that he died in 1994 at the age of 55. The actual year could be 1938, or 1939, or 1940 .
} 
his base university, he started to formulate and disseminate what would become the Sikolohiyang Pilipino (Filipino Psychology), otherwise known as sikolobiyang mapagpalaya (liberation psychology). In 1975, he convened the First National Conference on Filipino Psychology. ${ }^{33}$

He defines Sikolohiyang Pilipino as the systematic and scientific study of the Filipino "psychological make-up, society and culture" by Filipinos and for Filipinos. $^{34}$ Enriquez believes that the Western psychological models are not only inadequate and inappropriate in profiling the Filipino mind but are themselves instruments of colonization. By producing distorted understanding of ourselves and our world, Western psychology pull us deeper into the mire of colonial domination. Sikolohiyang Pilipino, or sikolobiyang mapagpalaya, carries with it a programmatic project of multiple liberations. First, by shifting its focus on the "appreciation and application of indigenous knowledge," it is thought of as liberation of Filipino psychology from Western theories..$^{35}$ Second, by affirming the Filipino identity, it is envisioned as liberation of the Filipino mind from colonial inferiority complex. Third, by bringing psychology to the level of popular culture, it is intended to liberate the less fortunate Filipinos from economic, cultural, and political oppression.

Enriquez identifies some of the promising areas where his followers may focus their various researches: the psychology of children, games, food, emancipatory struggles, the different levels of relating to one's fellowmen, healing practices, the discourse of the anting-anting (charms and amulets), literature, arts, "and other aspects of popular and folk practices expressive of a different consciousness or, simply, of a different way of being." 36

He emphasizes that our local research methods should be sensitive to the "cultural characteristics of the Filipino." 37 Hence, instead of blindly following the Western research protocols, he proposes that the local scholars should employ the following native ways of knowing: "pagtanong-tanong ("asking around"), pakikiramdam ("shared inner perception"), panunuluyan ("staying with"), and pakikipamubay ("living with"), among others." 38

Enriquez died from cancer in 1994, at the age of 55, leaving behind not only a number of followers and sympathizers for his postcolonial project, but also a formal organization Pambansang Samahan ng Sikolobiyang Pilipino (National Association of Filipino Psychology), as well as research center Akademya ng Sikolohiyang Pilipino (Academy of Filipino Psychology).

${ }_{33}$ Mendoza, op cit., 64.

${ }^{34}$ Virgilio G. Enriquez, Colonial to Liberation Psychology: The Philippine Experience (Manila: De La Salle University Press, 1994), 27.

35 Ibid., 28.

${ }^{36}$ Mendoza, op cit., 64.

${ }^{37}$ Enriquez, op cit., 27.

38 Ibid. 


\section{RICHARD RORTY'S POLITICAL PHILOSOPHY}

\section{Covar and Pilipinolohiya}

Prospero R. Covar (Born: 1934), earned his bachelor's and master's degrees in sociology at the University of the Philippines, and his doctor's degree in anthropology at the University of Arizona. It was in the University of the Philippines, while working as a professor of anthropology, where he developed the discourse of Pilipinolohiya in collaboration with his friend Zeus Salazar.

Covar defines Pilipinolohiya as the systematic study of the Filipino psyche, culture, and society with the aim of building our national culture. ${ }^{39}$ As an inter-disciplinary study of Philippine culture, it analyzes language, arts, film, philosophy, religion, and all other local practices.

Covar and Salazar conceptualize Pilipinolobiya as our counter-discourse to the more popular and internationally recognized 'Philippine Studies'. For them 'Philippine Studies' is a Euro-American generated knowledge about the Philippines. As an exogenous discourse it has the tendency to distort their object, and as a colonial discourse it has a tacit motive of producing knowledge in order to gain tighter politico-economic control over its object. Pilipinolohiya, on the other hand, is the Filipino scholars' struggle to understand their own people, culture, and country. As an endogenous discourse it seeks to overthrow the predominating Western sociological frames to understand the Filipino in his own terms, and as a postcolonial discourse it aims to disable the cultural basis of our neo-colonial present.

The proponents of the Pilipinolohiya achieved a momentous tactical victory when Salazar became the dean of the College of Social Sciences and Philosophy of the University of the Philippines, and appointed Covar as the coordinator of the just over a decade old Philippine Studies program in 1989. Covar strategically translated the name 'Philippine Studies' into Pilipinolobiya, endowing the program with their postcolonial philosophy.

After serving their administrative terms, however, the name of the program was re-translated as Araling Pilipino. Nevertheless, the two theorists are convinced that they have already created in the minds of the Filipino scholars the clear distinction between the colonial and exogenous 'Philippine Studies' and the postcolonial and endogenous Pilipinolobiya. ${ }^{40}$

\section{Salazar and Pantayong Pananaw}

Zeus A. Salazar (Born: 1934) earned his bachelor's degree in history at the University of the Philippines, and his doctor's degree in ethnology at the Sorbonne University of Paris. He had special trainings at the Ecole Nationale de Langues Orientales Vivantes in Paris, Freie Universitat Berlin, and Universiteit te

39 Quoted by Zeus Salazar, "Philippine Studies and Pilipinolohiya: Past, Present and Future of Two Heuristic Views in the Study of the Philippines," in The Malayan Connection: Ang Pilipinas sa Dunia Melayu (Quezon City: Palimbagan ng Lahi, 1998), 311.

${ }^{40}$ Mendoza, op cit., 90. 
Leiden. It was in the University of the Philippines, while working as a professor of history, where he developed the discourse of Pantayong Pananaw, reputed to be the most theoretically advanced and research productive among our local postcolonial discourse. ${ }^{41}$

Ramon Guillermo, in his essay Exposition, Critique and New Directions for Pantayong Pananaw, translates Pantayong Pananaw as "from-us-for-us perspective."42 It is a discourse about the Filipinos, constructed by the Filipinos, intended for the Filipino readers, and aimed at building the Filipino nation.

If Enriquez considers Sikolohiyang Pilipino as our counter-discourse to the Western psychological theories; and Covar, Pilipinolohiya to 'Philippine Studies'; Salazar's Pantayong Pananaw finds its discursive Other in what he calls the Pangkaming Pananaw, which Guillermo translates as "from-us-for-you perspective." The historiographies of Teodoro Agoncillo and Renato Constantino, although postcolonial in their own right, would still belong to Pangkaming Pananaw, for the reason that they are still shackled by the semiconscious motive of writing about the Filipinos for Anglophone Western readers, or at least universal readers. ${ }^{43}$ Following Guillermo's translation, Covar's Euro-American generated 'Philippine Studies' would be a discourse coming from a from-them-for-all perspective, a Pangkayong Pananaw, or Pangsilang Pananaw.

The foundational postcolonial strategy of Salazar is to expel the domineering presence of the Euro-American Other in the Filipinos' discourse about their own selves. This presence could vary from the actual writing of a Euro-American scholar about the Philippines, to the more rampant process of a Filipino scholar's naïve usage of a Euro-American social theory, or to the more subtle and often semi-conscious intention of a Filipino scholar of being understood by a wider Anglophone readership. The first kind of presence had already been attacked fatally by Covar's Pilipinolobiya, while the second kind of presence by Enriquez' Sikolohiyang Pilipino. Salazar's Pantayong Pananaw most specifically attacks the third mode of the Euro-American Other's presence in our discourse. For him the conscious, or semi-conscious, desire of a Filipino scholar to be understood by a wider Anglophone readership would only goad him to study the Philippine realities using Euro-American terms, thereby endowing his discourse with a deep-seated tendency to distort its object.

By making it clear at the outset that a Filipino scholar's discourse is solely for the Filipino people and their task of nation building, it would be much easier to study the various Philippine realities in their own terms. Mendoza elaborates: "That way, he (Salazar) argues, Filipinos can discourse and communicate freely - in their own terms, in their own language, using their

\footnotetext{
${ }^{41}$ Cf. ibid.

42 Ramon Guillermo, "Exposition, Critique and New Directions for Pantayong Pananaw," in Kyoto Review of Southeast Asia, March 2003, <http://kyotoreview.cseas.kyotou.ac.jp/issue/issue2/article 247.html>, 02 October 2007.

${ }^{43}$ Ibid.
} 


\section{RICHARD RORTY'S POLITICAL PHILOSOPHY}

own thought patterns and manner of relating and, most importantly, with their own interests (as Filipinos) kept in mind first and foremost." 44

At 73 years old, Salazar is still at the peak of his intellectually productivity, remains in control of the organization Bagong Kasaysayan, and had already left a lasting influence on a generation of younger scholars. Presently, Guillermo would state, Pantayong Pananaw is no longer an exclusive work of Salazar, but of "Jaime Veneracion, Nilo Ocampo, Ferdinand Llanes, Portia Reyes, Efren B. Isorena, Vicente C. Villan, Mary Jane Rodriguez-Tatel, Jose Rhommel B. Hernandez, O.P., Myfel Joseph Paluga, Nancy Kimuell-Gabriel . . . Atoy M. Navarro," and many more as well. 45

\section{Fortifying Philippine Postcolonialism with Rorty's Neopragmatism}

After more than half a century of existence, after their full emergence in the 1950s, the scattered Philippine postcolonial discourses remained largely confined within the progressive academic centers, where they are not even considered the dominant paradigms but merely alternative approaches. They have yet to make a substantial impact on the resilient academic discourses nationwide, as well as on the much more resilient Filipino colonial mind.

There seems to be some epistemological, political, directional, and modal difficulties obstructing the spreading out of these discourses. In this section, we are going to take a closer look at these hindrances through the lens of Rorty's neo-pragmatic political philosophy, with the intention of imagining possible Rortian-inspired solutions and remedies.

The first of these hindrances is the hegemonic presence of empiricist and positivist social sciences in our academe. Their adherents would expectedly sneer at our local postcolonial scholars' nationalistic and anti-EuroAmerican researches, which for them would be tantamount to a wanton disregard for the social sciences' commitment for objectivity, neutrality, and discursive universality. In academic settings where these empiricist and positivist scholars are more often than not the reigning intellectuals, our local postcolonialism would have tremendous difficulties in thriving, and much more in proliferating.

The second of these hindrances is the dialectical inversion of the first hindrance; that is, the postmodern modes of inquiry that were able to slip through the old empiricist and positivist guards to become a rather powerful undercurrent in our academe. If the hegemony of empiricism and positivism is already inhospitable to our postcolonial endeavors, its anti-thesis proved to be even hostile. While our local postcolonial intellectuals are engrossed theorizing about the nation, nation building, national identity and the Filipino, these postmodern modes of inquiry suddenly swept through them and declared their key concepts nothing but floating signifiers, or words devoid of any contents.

\footnotetext{
44 Mendoza, op cit., 93.

45 Guillermo, op cit.
} 
"A common judgment is that the once fashionable 'indigenization' movements of the 1980s," Guillermo writes, "have been rendered passé by the late 'postmodern' 1990s." 46

The resistance put up by empiricism and positivism on one hand, and the scathing conceptual implosions inflicted by postmodernism could be surpassed and eluded if our local postcolonialism would take shelter under Rorty's neo-pragmatic epistemology. Following Rorty, our scholars and students should be edified to think that after the linguistic turn, it is the hegemony of empiricism and positivism which is the one that is rendered passé. The old empiricist and positivists guards are therefore not much of a problem, unlike the nihilistic forces brought about by the same linguistic turn and postmodernism.

Rorty insists that even in a world without essences, philosophy, the natural sciences, the social sciences, cultural studies, and all other discourses, including postcolonialism, could still exist. Randolf David, one of our few local followers of this American neo-pragmatist, asserts: "Rorty's admonition that "sociologists and psychologists might stop asking themselves whether they are following rigorous scientific procedures, and start asking themselves whether they have any suggestions to make to their fellow citizens about how our lives, our institutions, should be changed" speaks to me profoundly and painfully. ${ }^{47}$ To refuse to surrender to the epistemological chaos sown by both the linguistic turn and postmodernism means to stop gauging a discourse in terms of its relationship to objects and essences, and to begin gauging it terms of its capacity to create and build a better future for humanity, where more freedom, more growth, more empathy, and more solidarity can be achieved.

Following Rorty's neo-pragmatic epistemology, we may re-imagine our local postcolonialism, as a tool, or more dramatically, a weapon, that we may use in rectifying the problems and violence inflicted on us by Spain and America. Postcolonialism should be our way of hoping for a better future. Under Rorty's neo-pragmatism, then, our local postcolonialism would not only be epistemologically legitimized, but would be endowed as well with an ethical force; for under this philosophy, actions that are effective in creating a better future for humanity are seen as morally superior to actions that are ineffective.

The third of these hindrances is the vulnerability of our nationalistic postcolonialism from fascist and capitalist subversions. Ma. Cynthia Rose Banzon-Bautista, in her essay The Social Sciences in the Philippines, presents the strife that ripped apart the nationalist solidarity among the intellectuals at the University of the Philippines: "At the height of authoritarian rule, social scientists exchanged polemical barbs. Those who worked with the Marcos administration were accused of legitimizing its dictatorial designs and the crony capitalism it fostered. On the other hand, those critical of colleagues who

\footnotetext{
46 Ibid.

47 Randolf David, "Sociology in the Postmodern World," in Philippine Sociological Review,
} 46:1-2 (January-June 1998), 5. 


\section{RICHARD RORTY'S POLITICAL PHILOSOPHY}

worked with government were charged with hiding in their ivory tower, unmindful of pressing societal problems." 48

In the 1970s, Covar was already drawn into the Philippine Center for Advanced Studies (PCAS), the identity of the University of the Philippine's Asian Center in the years 1973 to 1979 when Ferdinand Marcos tasked it to work for his policy, strategy, and ideological needs. ${ }^{49}$ Aside from its usual teaching and research activities, it appeared that the PCAS collaborated with the dictator on a general "Cultural Liberation Program" that included among other things the more specific "Pre-Departure Orientation Seminars" for all government workers who were leaving for some specific assignments abroad. ${ }^{50}$ Salazar was similarly lured into the same academic center, but had a deeper involvement with the dictator's ideological schemes. Together with Dr. Serafin Quiason, Dr. Romeo Cruz, Dr. Samuel Tan, and many other nationalist intellectuals, he ventured to ghostwrite Marcos' multivolume historical work, the Tadhana. ${ }^{51}$

Among the triumvirate of our local indigenization movement, it is only Enriquez who was spared from a compromising association with the fascist regime. Of the three indigenizing discourses, it was Sikolohiyang Pilipino that contains the most revolutionary impulse, for it promises to liberate the less fortunate Filipinos from economic, cultural and political oppression. However, the forces of capitalism and Imperialism seemed to have succeeded in doing what Marcos failed to do. Recording, broadcast and consultancy outfits swiftly appropriated the indigenizing insights of Sikolohiyang Pilipino for the service of capitalism, subverting the movement's revolutionary impulse and converting it into a commodity or a tool for selling other commodities. ${ }^{52}$ At the height of his intellectual prowess, Enriquez was enticed to various places in Asia and America to lecture on the Diaspora and comparative psychology, draining his energies and distracting him from the much needed theoretical and organizational tasks left in Manila. Captivated to address a growing Anglophone audience, he set aside his commitment to speak and think in the Filipino language. At one point, Salazar accused him of betraying the philosophy of indigenization..$^{53}$

Even Agoncillo, the father of our nationalist historiography, was not able to escape the discursive subversion of the Marcos regime. Reynaldo Ileto, one of the leading Filipino historians and historiographers, comments: "Agoncillo especially was co-opted by the Marcos state . . Agoncillo's

48 Maria Cynthia Rose Banzon-Bautista, "The Social Sciences in the Philippines: Reflections on Trends and Developments," in Philippine Studies, 48: Second Quarter (2000), 197.

${ }^{49}$ Cf. Mendoza, op cit., 58.

${ }^{50}$ Ibid.

51 Cf. Zeus Salazar, "Ang Historiograpiya ng Tadhana: Isang Malayang PaggunitaPanayam," in Paksa, Paraan at Pananaw sa Kasaysayan: Ulat ng Unang Pambansang Kumperensya sa Historiograpiyang Pilipino (Quezon City: UP-Departamento ng Kasaysayan, 1989), 193-199.

${ }^{52}$ Cf. Mendoza, op cit., 67-68.

53 Ibid., 77. 


\section{F. DEMETERIO}

history and Marcos' history were the same banana, or the same thing." ${ }_{54}$ Constantino, although rabidly anti-Marcos, unfortunately gravitated into the lair of a feudal, industrialist and capitalist group, the Lopez family. Mendoza mentions other intellectuals whose commitments to nationalism were blemished by their stint at the PCAS: the sociologist Ruben Santos-Cuyugan, the anthropologists Juan Francisco and F. Landa Jocano, the political scientist Eric Lacanlale, International Studies experts Josefa Saniel, Armando Malay, Jr., Roxy Lim and Benito Lim, and many more. 55

These scholars might have worked without sharing the regime's malice, and might have been too sincere with their nationalistic fervor, but their very alliance had revealed clearly how vulnerable our local postcolonialism is to fascist and capitalist exploitation. Without condemning them, the fact remains that their involvement with Marcos had dampened the enthusiasm for nationalism and anti-colonialism of the other more politically stringent scholars and sympathizers. The past may be the past, and there are more and more intellectuals who tend to forgive even Heidegger for his membership with Adolf Hitler's Nazi party, but no one should also stop us from learning from our collective experiences to prevent any possible repetition of such fascist and capitalist subversions. To give our local postcolonial scholars a fuller perspective of the present, it would be advantageous for them to take a similar position that Rorty took, the left. From the perspective of the left, fascism and unrestrained capitalism would appear more clearly as suspicious and terrifying forces. Just as Rorty called the American left, the party of hope, we may also call the leftist perspective, the position of hope.

Closely related to the third hindrance is the fourth one which has something to do with the parallelism between our local postcolonialism and the American cultural left. Although our postcolonial discourses share nothing of the American cultural left's timbre of hopelessness, pessimism, and the feeling of shame for their country, the two discourses are similar in their lack of attention to the economic and political components of oppression. Sikolobiyang Pilipino, Pilipinolohiya and Pantayong Pananaw might be professing to be interdisciplinary movements, and indeed to a large extent they are, we have to admit the fact that they lack substantial following among the local political scientists and economists.

Philippine postcolonialism, consumed as it is with burning hope, dazzling optimism, and exuberant pride for our country, should not be contented in 'psychoanalyzing' the colonial present. It should heed Rorty's admonition for the American cultural left, that it should move forward by coming up with concrete legislative and action-oriented suggestions that are capable of making the future more humane with more freedom, more growth, more empathy and more solidarity. There seems to be an urgent need for our

\footnotetext{
${ }^{54}$ Reynaldo Ileto, "Discussion on Reynaldo Ileto's Paper 'On the Historiography in the Philippines'," in Workshop 2001 for the Academic Frontier Project, Institute for International Studies, Meiji Gakuin University, <http://www. meijigakuin.ac.jp/ iism/frontier/Proceedings/ 11\%20Discussion2.pdf>, 11 October 2007, 4.

55 Mendoza, op cit., footnote 11, 58-59.
} 


\section{RICHARD RORTY'S POLITICAL PHILOSOPHY}

postcolonial discourses to dialogue with the isolated political and economic theories of our local scholars such as Walden Bello, Ricardo Ferrer, Temario Rivera, Edilberto Villegas and Joel Rocamora, who study not only the local modes of oppression but the global as well.

Closely related to the fourth hindrance is the fifth one which has something to do with the still inadequate alliance of our postcolonial theories with the other disciplines, especially with the more creative and emotive discourses, such as literature, the arts, popular culture, and mass communication. Rorty's neo-pragmatism has de-emphasized the boundaries between disciplines and has placed the stress, instead, on their collective tasks of generating new languages and vocabularies that are leading towards a desired change. "The method," he argues, "is to redescribe lots and lots of things in new ways, until you have created a pattern of linguistic behavior which will tempt the rising generation to adopt it." ${ }^{56}$

Alliance with literature, the arts, popular culture, and mass communication is very crucial because they can more powerfully reinterpret the present and affectively slither into the convictions of the Filipinos. Rorty's philosophy suggests that our local postcolonialism should be thoroughly interdisciplinary in its generation of a new way of thinking that would surpass our colonial culture.

The sixth of these hindrances has something to do with the purism, exclusivity, and inwardness of our three leading postcolonial discourses. Because of their collective strategy of understanding the Filipino in his own terms using his own language, they have the tendency to draw out a smaller and smaller circle of discursive legitimacy. Such a small circle prohibits the intellectual participation of scholars who are Western, or Anglophone, or Filipino using imported frameworks. Patricio Abinales, a leftist theorist in the Diaspora who himself feels being a victim of this discursive elimination, notes that it is this same purism, exclusivity and inwardness among the social scientists of the University of the Philippines that is already generating harmful signs of intellectual inbreeding. ${ }^{57}$ Guillermo, on the other hand, is trying to persuade the current exponents of Pantayong Pananaw to address the problem of linguistic exclusivity by establishing "communication and translation protocols" so as to "facilitate a more productive intellectual interaction between Filipino and English language traditions in Philippine social sciences." 58

The concerns of Abinales and Guillermo would become more urgent when read side by side with Rorty's critique of globalization. For Rorty, communication channels should be opened up, not in order for us to do business with, or to get an employment from, the global overclass, but in order for the leftist intellectuals of all nations to band together and raise their fellow citizens' consciousness about the dangers and threats spawned by globalization.

\footnotetext{
${ }_{56}$ Rorty, Contingency, Irony, Solidarity, 9.

57 Patricio Abinales, "Question of Location," in Korakora Projects $<$ http://www.korakora.org/projects/?q=node/71 >, 02 October 2003.

${ }^{58}$ Guillermo, op cit.
} 
Under the dispensation of globalization, there is a strong pressure for our local postcolonialism to more and more relax its principles of purism, exclusivity and inwardness. The leftist intellectuals of the world have the global burden of pressuring their respective governments to lobby for a more powerful global polity that would be capable of moderating and controlling the otherwise immoderate and uncontrollable transnational corporations.

\section{Conclusion}

This paper, therefore, had explored the political philosophy of Rorty by examining his concept of truth, ethical theory, notion of philosophy, general political theory, critique of the American left, and his critique of globalization. Then, it studied our postcolonialism, specifically its emergence and its three most robust movements, Enriquez' Sikolohiyang Pilipino, Covar's Pilipinolobiya, and Salazar's Pantayong Pananaw. It proceeded to unearth some of the problems that are hindering our local postcolonial discourse from succeeding in altering the widespread and well-ingrained Filipino colonial mind. As it analyzed the problems from the hegemony of empiricist and positivist social sciences, the presence of postmodernism, the episodes of fascist and capitalist subversions, the lack of economic and political perspectives, the lack of alliance with the more creative and emotive discourses, and our postcolonialism's inherent tendency towards purism, exclusivity and inwardness, this paper attempts to offer possible Rortian-inspired solutions and remedies.

Privileging Rorty's neo-pragmatic philosophy as the framework of critiquing our local postcolonialism will definitely not make the majority of our local theorists happy. But this paper, definitely, chose Rorty as an analytic tool not because he is an Anglo-American philosopher, but because he tackled issues that have striking resonances with what is happening to our local theorizing. After closely studying his neo-pragmatic philosophy, it becomes undeniable that he possesses a trove of lessons that would be very useful in further developing postcolonial thought in the Philippines. Salazar, one of the staunchest guard against theoretical borrowings, leaves a small door open for this kind of activity as long as the theories are "properly nuanced and critically appropriated to suit the Filipino context." 59

Department of Filipino, De La Salle University-Manila, Philippines

\section{References}

Abinales, Patricio, "A Question of Generations: Discussion on Reynaldo Ileto's Conference Paper," in Workshop 2001 for the Academic Frontier Project, Institute for International Studies, Meiji Gakuin University, <http://www.meijigakuin.ac.jp/ iism/frontier/Proceedings/10\%20C ommentary $\% 202 \% 20$ P.N.Abinales.pdf $>, 10$ October 2007.

${ }^{59}$ Mendoza, op cit., 86. 


\section{RICHARD RORTY'S POLITICAL PHILOSOPHY}

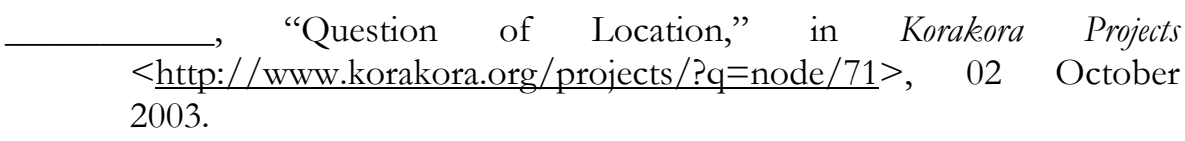

Abrera, Bernadette and Dedina Lapar eds., "Malayang Talakayan: Ikalimang Araw: Marso 31, 1989," in Paksa, Paraan at Pananaw sa Kasaysayan: Ulat ng Unang Pambansang Kumperensya sa Historiograpiyang Pilipino (Quezon City: UP-Departamento ng Kasaysayan, 1989), 208-217.

Adleman, Dan, "Richard Rorty, 1931-2007," in The Republic of East Vancouver, 166 (June 21-July 4, 2007) <http://www.republicnews.org/archive/166-repub/166_adleman.htm>, 14 September 2007.

Antolihao, Lou, "Modernity and the Underdevelopment of Sociological Theory in the Philippines," in Philippine Sociological Review, 47 JanuaryDecember 1999), 1-8.

Balco, Bryan, Limos, Loise Laine and Jacqueline Chua, "Si Zeus sa Tuktok ng Mt. Olympus," in The Bedan: Opisyal ng Pahagan ng mga mag-aaral ng Kolebiya ng San Beda-Mendiola, $65: 4$ (August 2007).

Banzon-Bautista, Maria Cynthia Rose, "The Social Sciences in the Philippines: Reflections on Trends and Developments," in Philippine Studies, 48 (2000), 175-208.

Best, Steven and Kellner, Douglas, "Richard Rorty and Postmodern Theory," in UCLA Graduate School of Education and Information Studies < http://www.gseis.ucla.edu/faculty/kellner/essays/richardrortypostm oderntheory.pdf>, 14 Sept 2007.

Cruz, Romeo, "Ang Paggawa ng Tadhana Mula 1980," in Paksa, Paraan at Pananaw sa Kasaysayan: Ulat ng Unang Pambansang Kumperensya sa Historiograpiyang Pilipino (Quezon City: UP-Departamento ng Kasaysayan, 1989), 200-203.

David, Randolf, "De-Professionalizing Sociology," in Reflections on Sociology and Philippine Society (Quezon City: University of the Philippines Press, 2001), 3-14.

, "Philippine Sociology: In Search of an Alternative Agenda," in Reflections on Sociology and Philippine Society (Quezon City: University of the Philippines Press, 2001), 15-28.

"Sociology in the Postmodern World," in Philippine Sociological Review, 46:1-2 (January-June 1998), 76-84.

Enriquez, Virgilio, Colonial to Liberation Psychology: The Philippine Experience (Manila: De La Salle University Press, 1994).

Fernadez, Erwin Soriano, "Decolonizing the Filipino: Cultural Intellectual Revolution in Contemporary Phillippines," in Asia Culture Forum 2006 $<$ http://www.cct.go.kr/data/acf2006/aycc/aycc1402Erwin\%20Sorian o\% 20Fernandez.pdf $>, 03$ October 2007.

Guillermo, Ramon, "Exposition, Critique and New Directions for Pantayong Pananaw," in Kyoto Review of Southeast Asia, (March 2003) $<$ http://kyotoreview.cseas.kyoto-u.ac.jp/issue/issue2/article_247. html>, 02 October 2007. 
Guerrero, Leon Ma., "The Strange Ratooning of Filipino Nationalism," in We Filipinos (Manila: The Daily Star Publishing Company, 1984), 54-58.

Haack, Susan, "Pragmatism: Addendum," in Encyclopedia of Philosophy, Vol. 7. Second Edition (Detroit: Thomson Gale, 2006), 749-750.

Ileto, Reynaldo, "Discussion on Reynaldo Ileto's Paper 'On the Historiography in the Philippines'," in Workshop 2001 for the Academic Frontier Project, Institute for International Studies, Meiji Gakuin University $<$ http://www.meijigakuin.ac.jp/ iism/frontier/Proceedings/11\%20 Discussion2.pdf $>, 11$ October 2007.

Jose, F. Sionil, "The Solidarity Interview with Teodoro Agoncillo," in Conversations with Teodoro Andal Agoncillo (Manila: De La Salle University Press, 1995), 145-191.

Lopez, Muriel, "An Intellectual History of Virgilio Enriquez," in Office of Institutional Research of California State University, San Bernardino

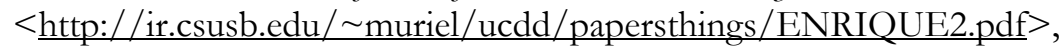
04 October 2007.

Lynch, Michael, "Richard Rorty," in Encyclopedia of Philosophy, Vol. 8. Second Edition (Detroit: Thomson Gale, 2006), 493-495.

Mendieta, Eduardo, "Postcolonialism," in Encyclopedia of Philosophy, Vol 7. Second Edition (Detroit: Thomson Gale, 2006). 726-729.

Mendoza, Lily, Between the Homeland and the Diaspora: the Politics of Theorizing Filipino and Filipino American Identities (Manila: UST Publishing House, 2006).

Nystrom, Derek and Kent Puckett, "Against Oligarchies: A Conversation with Richard Rorty," in Prickly Paradigm Press, Chicago < http://www.pricklyparadigm.com/paradigm3.pdf $>, 14$ September 2007.

Pertierra, Raul, "Introduction: From Society of Prowess to a Knowledge Regime," in Philippine Localities and Global Perspectives: Essays on Society and Culture (Quezon City: Ateneo de Manila University Press, 1995), 1-14.

Pineda, Ofreneo, "Renato Constantino: Biographical Sketch, Ideological Profile," in Partisan Scholarship: Essays in Honor of Renato Constantino (Manila: Journal of Contemporary Asia Publishers, 1989), 1-10.

Rood, Steven, "Nationalism and the Filipinization of Social Sciences," in Culture of Nationalism in Contemporary Philippine Society: Conference Proceedings (Baguio City: Cordillera Studies Center, 1995), 118-127.

Rorty, Richard, Achieving Our Country: Leftist Thought in Twentieth-Century America (Cambridge, Massachusetts: Harvard University Press, 1998). Contingency, Irony and Solidarity (Cambridge: Cambridge University Press, 1989). , Pbilosophy and Social Hope (London: Penguin Books, 1999). Philosophy and the Mirror of Nature (Princeton, New Jersey: Princeton University Press, 1979).

Rumana, Richard, On Rorty (Sidney: Wadsworth, 2000).

Salazar, Zeus, "Ang Historiograpiya ng Tadhana: Isang Malayang PaggunitaPanayam," in Paksa, Paraan at Pananaw sa Kasaysayan: Ulat ng Unang 


\section{RICHARD RORTY'S POLITICAL PHILOSOPHY}

Pambansang Kumperensya sa Historiograpiyang Pilipino (Quezon City: UPDepartamento ng Kasaysayan, 1989), 193-199.

, The Malayan Connection: Ang Pilipinas sa Dunia Melayu (Quezon City: Palimbagan ng Lahi, 1998).

San Juan, Epifanio Jr., "Prospects for Transformation in the Philippines in the Next Millenium," in the Austrian-Pbilippine Website <http://www.univie.ac.at/Voelkerkunde/apsis/aufi/ history/sonny2. $\underline{\mathrm{htm}}>$, 02 October 2007.

, "Reactionary Tendencies in the U.S. Production of Knowledge About the Filipino/The Philippines," in Bulatlat.Com, 40 (November 2001) < http://www.bulatlat.com/archive2/040sanjuan.html > , 04 October 2007.

Thayer, H.S., "Philosophical Schools and Doctrines: Pragmatism," The New Encyclopedia Britannica: Macropedia, 15 ${ }^{\text {th }}$ Edition (Chicago: Encyclopedia Britannica Inc., 1992), 636-640. " "Pragmatism." Encyclopedia of Philosophy, Vol. 7. Second Edition (Detroit: Thomson Gale, 2006), 741-748.

Tiongson, Nicanor, Doronilla, Ma. Luisa, Guillermo, Alice, and Fe Mangahas, "The Ideology and Cutlure of the New Society," in Synthesis: Before and After February 1986: The Edgar M. Jopson Memorial Lectures (Manila: Edgar M. Jopson Memorial Foundation, 1986), 49-65.

Turner, William, "Pragmatism," in The Catholic Encyclopedia < http://newadvent.org/ cathen/12333b.htm>, 14 September 2007. 